Etnográfica

Revista do Centro em Rede de Investigação em

Antropologia

vol. 16 (3) | 2012

Vol. 16 (3)

\title{
Europe in crisis: grassroots economies and the anthropological turn
}

A Europa em crise: economias populares e a viragem antropológica

\section{Susana Narotzky}

\section{(2) OpenEdition}

Journals

Electronic version

URL: https://journals.openedition.org/etnografica/2145

DOI: 10.4000/etnografica. 2145

ISSN: 2182-2891

\section{Publisher}

Centro em Rede de Investigação em Antropologia

Printed version

Date of publication: 1 October 2012

Number of pages: 627-638

ISSN: 0873-6561

\section{Electronic reference}

Susana Narotzky, "Europe in crisis: grassroots economies and the anthropological turn", Etnográfica [Online], vol. 16 (3) | 2012, Online since 08 October 2012, connection on 11 February 2022. URL: http:// journals.openedition.org/etnografica/2145 ; DOI: https://doi.org/10.4000/etnografica.2145

\section{(c) (†) \&}

Etnográfica is licensed under a Creative Commons Attribution-NonCommercial 4.0 International License. 


\section{Europe in crisis: grassroots economies and the anthropological turn}

\section{Susana Narotzky}

This article proposes a new approach to economic processes, one that is grounded in anthropological knowledge. The chaotic management of the crisis expresses the failure of the dominant "economic" paradigm. The time seems ripe for a new methodology and a different theoretical framework altogether. It is time for "Economic" knowledge to address an entire realm of economic behavior that is central to how people deal with their material needs and expectations. Going back to the origins of anthropological approaches to economic practices, we need to observe and listen; we need to hear what people are saying with their actions and arguments about their actions. At the same time we also need to articulate these practices and understandings with other scales of action and meaning, with other logics.

KEYWORDS: crisis, grassroots economies, livelihood, economic anthropology, institutions, subprime mortgages.

A Europa em crise: economias populares e a viragem antropológica • O artigo propõe uma nova abordagem aos processos económicos, fundamentada no conhecimento antropológico. A gestão caótica da crise demonstra o fracasso do paradigma "económico" dominante. O momento atual exige uma metodologia nova e um enquadramento teórico completamente diferente. Está na altura de o conhecimento "Económico" se voltar para todo um universo de comportamento económico que é central na forma como as pessoas lidam com as suas e expectativas e necessidades materiais. Regressando às origens das aproximações antropológicas às práticas económicas, precisamos de observar e ouvir, temos de escutar o que as pessoas dizem com as suas ações e os seus discursos sobre as mesmas. Simultaneamente, devemos articular estas práticas e conceções com outras dimensões da ação e do significado, com outras lógicas.

PALAVRAS-CHAVE: crise, economias populares, modo de subsistência, antropologia económica, instituições, crédito hipotecário de alto risco.

NAROTZKY, Susana (narotzky@ub.edu) - Universitat de Barcelona; ICREA Acadèmia, Spain. 
IT IS ALL TOO OBVIOUS THAT EUROPE IS IN CRISIS, SPAIN IS IN CRISIS, Portugal is in crisis, and even those countries which are "emergent" seem only to be a few years away from the crisis, a crisis of some kind, an economic crisis of some kind that is always also political. ' We have become so accustomed to reading every day in the news about macroeconomic indexes that seem to explain what is going on and why, that we often forget that until quite recently, our lives went on without any knowledge of these numbers and predictive projections. But as we try to interpret and understand this often obscure analysis, that language and those concepts creep into our everyday lives in many different ways: we can hear ourselves talking about the banks' exposure to the Greek bonds and trying to figure what we should do with our savings; we can see ourselves angrily reacting to social benefit cuts while we decry the adjustment policy and claim for a stimulus policy; we ask for less inflation or more employment (or we ask for both in our inexpert naiveté). Every day we hear "experts", Nobel Prize winners and others, telling us what we (or our governments) should and should not do to get out of the crisis. But experts don't agree, and most of their advice does not seem very innovative: it is either neoKeynesian or neo-liberal, advocating more or less state intervention, either fiscal restraint or stimulus expenditure, but having the same faith in the need for "economic growth", raises in "productivity" and "competitivity", voicing the same idea that markets are the best means for fair distribution among citizens in a nation, and among nations in the world, and keeping the same silence around the inherent collusion between economic and political elites that has been the hallmark of the system.

We hear these experts and the policy makers that follow their cues talking about countries as if they were school children that have or have not done their homework properly (no han hecho los deberes), and about citizens as if they were ignorant (or wrong) about what their best interest is. Southern European citizens, we are told, have been living "above their means", which is to say they were never supposed really to converge with the wellbeing patterns that southerners had observed when they were "guest workers" in the North, in the 1950s and 1960s. While "experts" throw about contradictory messages about what macroeconomic policies should be, lack of respect for ordinary people on the part of the elites is growing and becoming quite explicit.

If we look around us at the angry responses of citizens - often also imbued of a certain "nationalist" defense of their honor - what we observe is a breakdown of trust, lack of trust in state institutions, in the aims of political representatives (los políticos), in economic institutions (banks), in the trickle down

1 This essay was originally presented as the 2011-12 edition of Aula Ernesto Veiga de Oliveira (Department of Anthropology at ISCTE-Lisbon University Institute, School of Human and Social Sciences), Lisbon, November 30th, 2011. 
effects of growth upon unemployment or labor rents. But also, increasingly, lack of trust in the model. Lack of trust in experts whose predictions made us act in particularly harmful ways to our immediate interests: for example, the real estate broker that confirmed the common knowledge that the housing market will always go up, or the financial agent that told us to invest our small savings in stock or bonds because in the long run the stock market always produces benefits. This is not to say that we did not have any responsibility regarding our actions. But we do resent that they do not accept any responsibility regarding their "expert" advice, any responsibility regarding the material results of that advice. Moreover, we do resent that they continue talking about "the" economy or "the" market as if it were a disembodied abstract mechanism, as if it were about mere "technical" decisions diluting the responsibility of human subjects. But the economy and the market concern real people in different positions of power, with different life projects and the ability to mobilize different kinds of resources within different timeframes. For most - the 99\% in Zuccotti Park or the Indignados in Spain - this is about trying to make a modest living and to see the next generations get started in a life project which is somewhat hopeful.

Expert economic analysis talks about the crisis without mentioning the plight of ordinary people, however. In a monographic issue of The Economist about "How to save the Euro" (September 17 th 2011 ) we find authoritative appeals to "structural reforms and liberalization" and advice about what countries, banks and high-power individuals such as Mrs. Merkel should do. But there is a conspicuous absence of any ordinary human being. The technical jargon of macroeconomics seems to be the only reality to be considered. The unvoiced corollary seems to be that that is what economy is all about. There is nothing else to consider. People become aggregates and abstractions as in "demand", or they become rational choice autonomous individuals as in "the consumer", with marginal utility drives that can be simulated in abstract models. Only when all predictions and models seem to be unable to explain the crisis, or the way indexes evolve against all odds in unforeseen directions and do not react in the predicted manner, only then mainstream economists think that the "fault" is with the human actor. And, following the hegemony of "technical" models, that "fault" or "error" must be due to irrational or emotional behavior, which needs to be understood. Mainstream economists, then, turn to psychology. Indeed, this underscores the fact that methodological individualism is the only congruent method in a mainstream economic framework made of mechanical metaphors and unambiguous "choices". As Dame Margaret Thatcher reminded us, in this model 'society' does not exist.

It is becoming more and more evident, however, that mainstream economic models do not explain nor help prevent major crises and their negative repercussions on general wellbeing and social cohesion. Why do they fail once and 
again? It is my hypothesis that the major behavioral axioms that sustain them are inadequate. Mainstream models are produced with little grounded knowledge about how real people make decisions within social and cultural environments that set the conditions of possibility for their actions. Because of their formalization requirements, these models are at pains to include much of what sustains actual human behavior: meaning, moral value, ambiguity, contradiction, affect, emotion, expectations and responsibilities. By neglecting or simplifying these complex processes, those models have in fact renounced to consider human subjects as real agents of economic processes.

Moreover, the regulating structure of economic behavior has been transformed in late capitalism: upscale, through the increasing power of transnational bodies upon national governments' decisions, and downscale, through forms of governance devolution to local and private actors. This re-structuring has produced a "cunning" state (Randeria 2007) and a "cunning" citizen (Glick-Schiller 2005). Increased ambiguity and tension regarding the framework of institutional responsibilities enhances the use of personalized ties to access resources (brokerage, patronage, corruption). The tension between formalized institutional procedures for regulating the economy and other forms of regulation is an issue we need to address as they overlap or diverge at different scales. In pursuing their livelihood, people have to negotiate the scales of macro economic models, meso institutional regulation and micro forms of responsibility that govern their actions (including filial, community, religious or state responsibilities). We need to explore how they/we manage in practice.

\section{AN ANTHROPOLOGICAL TURN}

In this Europe in crisis a grassroots approach to economic processes can only be engaged with the methodological instruments of anthropology. Here I want to follow the lead of three questions that point at the centrality of an anthropological turn for understanding economic behavior.

\section{What is the active participation of ordinary people in "the economy" as individuals and as groups?}

Here we are immediately confronted to classical anthropological issues, such as what the economy is for different groups of people. How do we deal with an "emic-etic" tension which has become embedded in ordinary practice as the "expert" discourse, disseminated through the media, has become hegemonic? How are "expert" concepts re-configured and understood and how do they mediate practice in the lives of ordinary people? This creates the methodological environment of the research in economic anthropology.

But mostly, what we want to address here is, very simply, how do people manage to get the material resources for life? How do they make projects 
for future generations and how do they act to fulfill those objectives? How is dependence produced (for example, through moral obligation) and what resources does it provide? How are these practices entangled with particular modes of responsibility? How do particular meanings of "good" and "bad" behavior (moral understandings) influence particular areas of interaction?

Classical anthropologists used to go anywhere and try to observe what people were doing in households, in the fields, in the workshops and markets; how they were doing it, how they related to each other in so doing; they tried to understand why they were doing it, why they thought they had to do it, what meanings and responsibilities constrained their actions (Malinowski 1961 [1922], 1961 [1926]; Bohannan and Bohannan 1968). They investigated what institutional forces were at play that could explain the recurrence of particular behavior over time. Another generation of anthropologists tried to articulate that observation with a model of wider scale logics of historical transformation (abstract etic models: neo-Marxist) (Wolf 1982; Mintz 1985). Yet another generation considered that the distinction between emic and etic models was a form of knowledge colonization that had to be substituted by a real epistemological openness to "other" economic models in a "pluriverse" framework of conversation, articulation, miscegenation (Escobar $2005 \mathrm{a}, 2005 \mathrm{~b}$ ) or a radical questioning of the ontological assumptions of the Enlightenment that supported the Western epistemological break (Descola and Pálsson 1996; Latour 1997).

As anthropologists we always had to deal, on the one hand, with the actual practices, autonomies and dependencies of the relational field and, on the other hand, with the various models and meanings that produce the field of forces that may "explain" these practices and their effects in the short and longer terms. Therefore, the anthropological approach provides a hands-on method to the understanding of ordinary people's economic behavior in late capitalist societies.

\section{How are existing institutions involved in the economic practices and projects of ordinary people?}

Here we are confronted with another of anthropology's main original interests, namely the forms of social regulation of provisioning and distribution that can be observed. Malinowski produced "reciprocity" as an institutional framework of distribution after analyzing the exchange behavior of the Trobrianders (1961 [1922]). Polanyi (1957) spoke of the different forms of institutionalizing the economy, by which he meant forms of regulating the distribution of material wealth. By pointing at distribution, Polanyi underlined the reproduction of particular positions in relation to wealth (and power), that is, the social reproduction of a particular human system of relations, a society. 
New institutional economists such as Douglass North (or Elinor Ostrom) have also focused on the relevance of institutions for explaining economic behavior and this has proven to be an important step away from the hegemonic methodological individualism of mainstream economics. North (1989, 1993) has pointed to "property" as the main institutional framework in contemporary capitalism, and has underlined the centrality of the norms and political organization that help stabilize this particular institution. Ostrom (1999), on the other hand, has underscored the communal forms of regulation of common natural resources that enable the reproduction of human communities and the conservation of the resources through negotiation and consensus. For anthropological thinking institutions have to be inferred from the observation of actual practice rather than being imposed as external concepts or forms of organization. This original methodological naiveté should be recuperated in our research, and should be vindicated in an attempt to break hegemonic forms of understanding the economy. For example, if we think of "property" as an institution, an anthropological approach will consider the normative framework and the organization for its implementation as only one aspect of what the institution might be in practice. As Chris Hann (1998) has suggested, we will generally be closer to the actual practical experience of "property" in most societies if we think of it as a "bundle of rights": different sorts of entitlements and responsibilities relationally operating in a social field. An alternative view is that of the Actor-Network Theory, where human and non-human subjects, material and discursive artifacts become entangled at particular conjunctures as "actants" in practice (Law 1999; Callon and Muniesa 2005). In this perspective, the category of "institution" itself looses its grounding, originally based on a social stabilization of human behavior over time.

Bourdieu's articulation of different "fields" of social interaction (cultural, symbolic, social, market fields) points to a similar awareness of complexity, but tries to resolve it differently (Bourdieu 1979). His approach takes into account distinct but complementary processes of value formation through recurrent - and hence, institutional - social interaction. Different values are understood as involved in a productive process, as Bourdieu's metaphor of access and management of different "capitals" underscores. Distinction, in turn, becomes a correlative principle of social reproduction, as different forms of "enclosure" or restriction of access to resources configure the fields of value. These various anthropological frameworks linked to an ethnographic approach allow for a better understanding of what "property" might mean to different social agents and underline its relational position as one form of available appropriation among others, one, moreover, that changes constantly beyond the attempts that might be generated to contain it. They support a different approach to institutions, one where the contours of the institutional frame are multiple and in tension. 
Institutions have to be studied in their concrete existence, as processes of formalization: literally, giving form, representing norms and practices as bounded units. They are fields of contending social forces, individual and collective, that are permanently changing but aim at creating a symbolic construct that produces stability through time. For Bourdieu (1982, 1986a, 1986b), one of the main assets of institutions is the performative effect of form, defining boundaries and creating durable difference that will stabilize human behavior. As frameworks for social reproduction they are bound to express a permanent tension between those in powerful positions - in their attempt to give form - and those in relatively powerless positions - able to challenge form through practice.

So the anthropological grassroots economies inquiry would try to observe how in everyday practice ordinary people in capitalist economies appropriate and distribute resources. Then it would follow up on how different manners of doing this are regulated by social frameworks of stabilization, by norms, values and organizations of various types. Understanding the social and cultural configuration of economic logics requires an anthropological approach to the realities of institutional form and practice for ordinary people on the ground.

\section{How do "expert" macroeconomic models and projections interact with ordinary people's projects and with institutional configurations and policy practice?}

Most research in this area is generally focused on the production of "expert" knowledge and its effects on entrepreneurial or financial activities. The linguistic concept of performativity has become central to this perspective (Callon 2007). Performativity is an issue of power: the power of making things happen just by the enunciation of their happening. We are witnessing every day the power of rating agencies (Standard \& Poor, Moody, Fitch) over financial assets, governments and citizens. The power of enunciation, however, is predicated on belief, which is a social construct. Several of our colleagues are working with the production of standards and "conventions" that operate in mainstream economic logic and processes, mostly among "expert" agents (Holmes 2009; Holmes, Marcus and Westbrook 2006). The former underscore how the latter make things happen by producing formalized or informal expectations, and particular environments of trust. In fact these conventions define a particular "moral economy" of capitalism (good practice, rational action, stability) (Sylvander 1997; Renard 2003; Boltanski and Thévenot 1991).

As anthropologists we have witnessed that grassroots forms of performativity also exist, for example when people create alternative currencies or earmark money for special uses (Zelizer 1997). Moreover, mainstream economic concepts are transmitted through the media and through particular agents with whom most people have recurrent interaction. We may ask, then: How do "expert" models and predictions affect economic decisions in everyday 
livelihood projects? Financialization of everyday life has become pervasive in Western economies. On the one hand, the welfare state has devolved to private means the responsibility of caring. On the other hand, credit-supported consumption and stock-market asset valorization have substituted for real wage increase in the social mobility prospects of many households. In this context the anthropological observation and analysis of how cultural meanings and social responsibilities produce particular practices that impact the use of these financial instruments becomes crucial. We cannot understand the credit and housing bubble without this knowledge, unless we renounce the agential capabilities of people and their relational substance. This, then, points to a grassroots performativity raising many questions: How diverse are grassroots models and how different are they from "expert" models? How "performative" are these grassroots models for the macroeconomic dynamics of the economy? How do people understand expert models in different social and cultural contexts and therefore what is "performative" about expert models?

We need to think at how organizations and institutions are involved in ordinary people's interaction with macroeconomic logics and financial predictions, but also, how practice on the ground - often informed by "other" logics -, inevitably transforms macroeconomic movements and expert predictions. Generally speaking, there is a need to acknowledge and analyze these "other" forms of performativity and assess their impact in the real economy.

\section{THE CASE OF SUBPRIME MORTGAGE IN CIUTAT MERIDIANA}

Let me give you an example of the approach I am advocating. I will briefly address a case of subprime mortgage crisis as it has occurred in Spain. Research for this case has been carried out for his PhD by Jaime Palomera in Barcelona (forthcoming).

Ciutat Meridiana is a peripheral neighborhood in Barcelona that was settled in the 1960s with immigrants from the South of Spain and has recently become home to increasing numbers of non-EU people. Many of them worked in the construction industry during the housing bubble and in the tourist service sector. As elsewhere in Spain, the accessibility of real estate investment opportunities and easy credit became a household saving strategy. During the period between 2003 and 2007 a million mortgages were granted in Spain to vulnerable segments of the society (including young people and immigrant population) (López and Rodríguez 2011). Arguably the housing structure in Spain has favored property over rental since the late 1950s and this trend increased in the 1990s. But various other issues were simultaneously at play. Immigrants were pushed into home acquisition by the difficulties faced in renting apartments, as the prices skyrocketed and the advanced deposit of several months' rent as securities imposed by owners upon immigrant tenants 
became an important obstacle. They were also attracted by the innumerable real estate agencies and local bank agents that mushroomed in the area, and by the prevailing hegemonic discourse of increasing income through housing property assets. For irregular immigrants owning a house was also a form of legally demonstrating the will to take roots (arraigo) that could be used for legalizing their irregular situation. Within the migrant networks, moreover, home owners were characterized by their prominent position as people with resources who had been able to accumulate capital, acquire property and lend or sublet it to other members of the network. But these property buyers with precarious income and insecure legal status had to rely on friends or family in order to access mortgage credit. A system of reciprocal collateral vouching became the norm. This has led to intensive commoditization of reciprocity relationships within the social network and to the solidifying of a structure of multiple dependencies. But it has also created the conditions of possibility for immigrants to participate in the processes of capital accumulation, both in their position as exploited construction workers (surplus value extraction in production), as consumers of housing property (realization of surplus value) and as credit takers (surplus value accumulation through financial circuits) (Palomera and Narotzky 2008).

When the bubble burst, these people were the first to lose their jobs, their incomes, and their houses. On the one hand, these precarious livelihoods partially depend on income provided by close kin or fellow migrant lodgers that help pay the mortgage expenses. On the other hand, as repossessions have become widespread banks are seeing their housing assets grow while their value decreases together with demand, and this has resulted in a major bank crisis. But the mortgage default situation has had other social and economic consequences. It has affected people's understanding of financial assets dependency as they experience the downside of it. It has affected their trust in "expert" financial advice, and their outlook on how to access resources such as housing. It has affected their position in networks of trust within migrant groups, for cross-collateralization has strained many close relations of mutual help and reciprocity, as the search for responsibilities often targets those with close intimate bonds. A complex web of dependencies and social meanings is being torn apart.

However, migrant groups are diverse within national affiliation and also in relation to other national groups. The strategies and "economic" understandings of, say, Ghanaians are different from those of citizens of the Dominican Republic. Ghanaians networks are widely spread in Europe, and informants express an "entrepreneurial" rationality which often supersedes national loyalties. Their accumulation strategies are oriented toward the homeland. The immigrants from Dominican Republic have denser networks and their long-term accumulation strategies are more ambivalent, as they seek family 
reunification and tend to invest in the host country. Many other issues were involved in migrants' decisions regarding housing investments during the bubble. The Evangelical Church drive toward accumulation in the case of Dominicans might have been quite significant in coupling a work ethic with property ownership. However, locally, religious affiliation cross-cuts some national boundaries as religious rituals and gatherings (Protestant, Catholic) bring together residents from different parts of the city and from different countries of origin. This helps the circulation of information on economic strategies, models and institutional resources. Time of residence in the host country also produces internal differentiation in groups, as their aims change and their exposure to host country resources and discourses are experienced in the long term.

Subprime mortgages were addressed to immigrants with no collateral at the peak of the housing bubble, through a system of cross-collateral vouching that distributed financial responsibility among networks of immigrants, using and stressing pre-existing trust networks (El País, English version, 27-12-2010). But why had property ownership in the host country (Spain) become a "project" of wellbeing? How did it compete with other responsibilities and wellbeing projects such as those tied to remittance sending to the home country? On which social basis was the system of cross-collateral ownership build? What assets (resources and claims) were mobilized around what sort of project of livelihood for present and future generations? If ordinary people are not just reactive subjects adapting their agency to the designs of experts and policy makers, then we need to understand how their projects and those of the economic elites are co-determined.

\section{CONCLUSION}

Social anthropology has always been shy in the face of "economics" with its "scientific", abstract modeling of rational actor's behavior. However, "economics" now is unable to account either for the "volatility" of the system, or for the extreme polarization of wealth in a system that fails to deliver the redistributive benefits of capitalist markets for the larger public. The chaotic management of the crisis expresses the failure of the dominant "economic" paradigm. The time seems ripe for a new methodology and a different theoretical framework altogether. It is time for "Economic" knowledge to address an entire realm of economic behavior that is central to how people deal with their material needs and expectations. In my opinion, anthropology has the key to this different understanding. Anthropologists are very well situated to undertake this methodological transformation because they have a strong tradition of asking questions, of not taking things for granted, of daring to ask obvious questions that are often responded in surprising ways. Going back to 
the origins of anthropological approaches to economic practices, we need to observe and listen; we need to hear what people are saying with their actions and arguments about their actions. We need to record how the responsibilities that frame people's actions are understood, what expectations have to be met and how is the effort to meet them valued. At the same time we also need to articulate these practices and understandings with other scales of action and meaning, with other logics. Then, we would be in a position to risk defining an alternative theoretical framework for understanding reality and struggling towards a better future, providing hope for the coming generations.

\section{REFERENCES}

BOHANNAN, Paul, and Laura BOHANNAN, 1968, Tiv Economy. Evanston, Northwestern University Press.

BOLTANSKI, Luc, and Laurent THÉVENOT, 1991, De la justification: les économies de la grandeur. Paris, Gallimard.

BOURDIEU, P., 1979, La distinction. Paris, Les Editions de Minuit.

BOURDIEU, P., 1982, "Les rites comme actes d'institution”, Actes de la Recherche en Sciences Sociales, 43: 58-63.

BOURDIEU, P., 1986a, "Habitus, code et codification", Actes de la Recherche en Sciences Sociales, 64: 40-44.

BOURDieU, P., 1986b, "La force du droit", Actes de la Recherche en Sciences Sociales, 64: 3-19. CALLON, Michel, 2007, "What does it mean to say that Economics is performative?", in D. MacKenzie, F. Muniesa and L. Siu (eds.), Do Economists Make Markets? On the Performativity of Economics. Princeton, NJ, Princeton University Press, 31 1-357.

CALLON, Michel, and Fabian MUNIESA, 2005, "Economic markets as calculative collective devices”, Organization Studies, 26 (8): 1229-1250.

DESCOLA, Philippe, and Gisli PÁLSSON (eds.), 1996, Nature and Society: Anthropological Perspectives. London, Routledge.

ESCOBAR, Arturo, 2005a, “El 'postdesarrollo' como concepto y práctica social”, in Daniel Mato (ed.), Políticas de Economía, Ambiente y Sociedad en Tiempos de Globalización. Caracas, Facultad de Ciencias Económicas y Sociales, Universidad Central de Venezuela, 17-31.

ESCOBAR, Arturo, 2005b, Más Allá del Tercer Mundo: Globalización y Diferencia. Bogotá, Instituto Colombiano de Antropología e Historia.

GLICK-SCHILLER, Nina, 2005, “Transnational urbanism as a way of life: a research topic not a metaphor”, City \& Society, 17 (1): 49-64.

HANN, C.M., 1998, "Introduction: the embeddedness of property", in C. M. Hann (ed.), Property Relations: Renewing the Anthropological Tradition. Cambridge, Cambridge University Press, 1-47. 
HOLMES, Douglas R., 2009, "Economy of words", Cultural Anthropology, 24 (3): 381-419.

HOLMES, Douglas R., George MARCUS, and David A. WESTBROOK, 2006, "Intellectual vocations in the City of Gold", PoLAR: Political and Legal Anthropology Review, 29 (1): 154- 179 .

LATOUR, Bruno, 1997, “The trouble with actor network theory”, Soziale Welt, 47 (4): 369-381 .

LAW, John, 1999, "After ANT: Complexity, naming and topology", in J. Law and John Hassard (eds.), Actor Network Theory and After. Oxford, Blackwell Publishers, 1-14.

LÓPEZ, Isidro, and Emmanuel RODRÍGUEZ, 201 1, “The Spanish model”, New Left Review, 69: 5-29.

MALINOWSKI, Bronislaw, 1961 [1922], Argonauts of the Western Pacific. New York, Dutton \& Co.

MALINOWSKI, Bronislaw, 1961 [1926], Crime and Custom in Savage Society. London, Routledge \& Kegan Paul.

MINTZ, S., 1985, Sweetness and Power: The Place of Sugar in Modern History. New York, Penguin Books.

NORTH, Douglass C., 1989, "Institutions and economic growth: an historical introduction”, World Development, 17 (9): 1319-1332.

NORTH, Douglass C., 1993, "The new institutional economics and development", available at <http://129.3.20.41/eps/eh/papers/9309/9309002.pdf>, access June $10^{\text {th }} 2011$.

OSTROM, Elinor, 1999, "Coping with tragedies of the commons", Annual Review of Political Science, 2: 493-535.

PALOMERA, Jaime, forthcoming, "Transitar y habitar la "ilegalidad": economías cotidianas migrantes” in S. Narotzky (ed.), Economías Cotidianas, Economías Sociales, Economías Sostenibles. Barcelona, Icaria.

PALOMERA, Jaime, y Susana NAROTZKY, 2008, "Regulation on the margins: informal networks and their effects on the social structure of a peripheral neighbourhood in Barcelona", paper presented at the International Sociological Association Forum, Barcelona, September 5-9.

POLANYI, Karl, 1957, “The economy as instituted process” en K. Polanyi, C. Arensberg and H. Pearson (eds.), Trade and Market in the Early Empires: Economies in History and Theory. New York, The Free Press, 243-269.

RANDERIA, Shalini, 2007, "The state of globalization: legal plurality, overlapping sovereignties and ambiguous alliances between civil society and the cunning State in India", Theory, Culture and Society, 24 (1): 1-33.

RENARD, Marie-Christine, 2003, "Fair trade: quality, market and conventions", Journal of Rural Studies, 19: 87-96.

SYLVANDER, Bertil, 1997, "Le rôle de la certification dans les changements de régime de coordination: l'agriculture biologique, du réseau à l'industrie", Revue d'Économie Industrielle, 80: 47-66.

WOLF, Eric R., 1982, Europe and the People Without History. Berkeley, University of California Press.

ZElizer, Viviana A., 1997, The Social Meaning of Money: Pin Money, Paychecks, Poor Relief, and Other Currencies. Princeton, NJ, Princeton University Press. 